\begin{tabular}{l} 
SCIENCE \& TECHNOLOGY \\
Journal homepage: http://www.pertanika.upm.edu.my/ \\
\hline PERTANIKA
\end{tabular}

\title{
Utilisation of Oil Palm Fibre Biomass Waste as Additives in Foamed Concrete
}

\section{Md Azree Othuman Mydin}

School of Housing, Building and Planning, Universiti Sains Malaysia, 11800, Penang, Malaysia

\begin{abstract}
Worldwide, the construction industry has acknowledged the future demand for lightweight construction materials, with high workability, self-compacting, and environmentally friendly. Given this demand, recent innovative material namely foamed concrete (FC), has been found to reduce normal concrete's weight potentially. However, while FC made with Ordinary Portland Cement has good compressive strength, other characteristics such as tension are relatively weak given the number of micro-cracks. Therefore, the study focused on the potential use of oil palm fibres in FC regarding their durability and mechanical properties. Notably, one of the major issues faced in the construction of reinforced FC is the corrosion of reinforcing steel which affects the behaviour and durability of concrete structures. Hence, in this study, oil palm fibres were added to improve strength and effectively reduce corrosion. Five types of fibre generated from oil palm waste were considered: oil palm trunk, oil palm frond, oil palm mesocarp and empty fruit bunch consisting of the stalk and spikelets. Specimens with a density of $1800 \mathrm{~kg} / \mathrm{m}^{3}$ were prepared in which the weight fraction of the fibre content was kept constant at $0.45 \%$ for each mixture. Testing ages differed in testing and evaluating the parameters such as compressive strength, flexural strength, tensile strength, porosity, water absorption, drying shrinkage and ultrasonic pulse velocity. The results showed that the incorporation of oil palm fibre in FC helped reduce water absorption, porosity and shrinkage while enhancing the compressive, flexural and tensile strength of FC.
\end{abstract}

Keywords: Bending, compression, foamed concrete, oil palm fibre, porosity, water absorption

ARTICLE INFO

Article history:

Received: 06 April 2021

Accepted: 05 July 2021

Published: 18 October 2021

DOI: https://doi.org/10.47836/pjst.29.4.27

E-mail address:

azree@usm.my

ISSN: 0128-7680

e-ISSN: $2231-8526$

\section{INTRODUCTION}

Concrete is one of the main materials used in the construction sector, given its versatility in terms of production and its environmental protection and recyclability. Concrete is still preferred as a material used 
for construction compared to timber, steel or composite materials. Naturally, concrete has higher compressive strength but lower tensile strength. Structures constructed from concrete materials also have a long service life. Composite's responses are formed when the concrete is incorporated with reinforced steel bars, and in this way, all types of actions can be sustained. However, the average concrete density is around $2400 \mathrm{~kg} / \mathrm{m}^{3}$, which often causes issues in larger open floor plans and high-rise buildings since it will be penalised due to its weight towards the project (Suhendro, 2014). It has become a major issue in the construction industry for the past few years, as the demand for high-rise buildings increases from year to year. Consequently, researchers and engineers continue to focus on addressing and overcoming this issue. Hence, foamed concrete (FC) has become the latest advanced material that could minimise the self-weight of the concrete. It can be made to have a density between $800 \mathrm{~kg} / \mathrm{m}^{3}$ to $1800 \mathrm{~kg} / \mathrm{m}^{3}$ (Serri et al., 2014). These characteristics have attracted building material manufacturers for construction applications. Therefore, oil palm fibre is one of the additives included in the FC mixture to enhance its properties.

In Malaysia's agricultural sector, oil palm is one of the main exports, which has helped develop the industry and the economy. Lignocellulosic biomass generated from oil palm industries comprises cellulose, hemicellulose, and lignin and is often referred to as plant biomass (Mohammadhosseini et al., 2016). Oil palm trunks (OPT), oil palm fronds (OPF), empty fruit bunches (EFB) and palm pressed fibres (PPF), palm shells, and palm oil mill effluent (POME) are included in this classification. However, major dumping issues result given the presence and volume of oil palm waste. Therefore, to solve this issue regarding biomass waste, the waste from the by-product of oil palm can be utilised as the infill material in FC to enhance its properties (Momeen et al., 2016). FC is a cellular cemented material acquired through the introduction of preformed foam into the cementitious matrix. Combining these materials leads to air voids built up within the material's underlying microstructure (Mahzabin et al., 2018). These natural fibres substitute other traditional additives such as steel and glass fibres which have previously been expansively utilised. This change in tendency is due to the added value that natural fibres bring to these materials, particularly from sustainability.

There is increasing attention to developing concrete bonded natural lignocellulosic fibre composites with improved durability and mechanical properties. These fibres provide a superior contact surface with the cement matrix, which significantly enhances its bond, gaining a more homogeneous material, thus, having better mechanical properties. The inclusion of lignocellulosic fibres, such as coconut fibre, oil palm fibre and jute fibre as reinforcement in cement-based composites, has been studied to in part substitute the synthetic counterparts, particularly glass and polymeric fibres in construction materials. Though, in addition to the problem of durability, there is the issue of the interface between the fibres with the cementitious matrix (Ezerskiy et al., 2018). Furthermore, the mechanical 
features of cement-based composites strengthened with natural fibres not only depend on the properties of the fibre itself but also on the degree to which an applied load is spread to the fibres by the matrix phase (Ferreira et al., 2017).

Moreover, deviations in the mechanical properties over time can transpire due to microstructural instabilities in the fibre-matrix boundary and bulk, as a sign of the continued hydration process in the fibre surroundings (Hasan et al., 2020). First, though, the growing porosity value of the cement composite in the interfacial region arises, as there is a variation of the water to binder proportion (Hospodarova et al., 2018). Then, there is a further encounter for the fibre-cement; the lignocellulosic fibres' hydrophilic nature hinges on the lumens, sorptivity, irregularity, chemical compounds and superficial energy in the fibre-matrix boundary (Karade \& Aggarwal, 2011). Therefore, it is crucial to control the fibre-matrix interface with lignocellulosic fibre, unlike synthetic fibres such as glass fibre. Lignocellulosic fibres have substantial disparities in chemical composition, diameter, and superficial coarseness ensuing in the important smattering in fibre mechanical properties (Li et al., 2020). For instance, with a non-uniform cross-section and composition along the longitudinal axis, the tensile strength of the oil palm trunk fibre is diverse between 115 to $165 \mathrm{MPa}$. The lignocellulosic fibre reinforcement bonding in cement-based materials remain comparatively unmapped (Mahmud et al., 2021).

Therefore, problems between the lignocellulosic fibre interface and matrix must be analysed inversely from composites reinforced with synthetic fibres, though comparable durability and mechanical strictures can be employed (Onuaguluchi \& Banthia, 2016). The contact can ensue over three mechanisms: mechanical coupling of the two materials, physical coupling such as van der Waals interaction, and covalent bonding between the fibre and the matrix (Kochova et al., 2020). These interactions produce an interphase region which is a three-dimensional region near the fibre with properties different from either the fibre or the matrix (Hasan et al., 2021)

In recent years, foresight groups worldwide have recognised the future demand for light, durable, economical and environmentally friendly construction materials to enhance eco-friendly products. It is anticipated that the current study will benefit many players in the construction industry, especially manufacturers and contractors since they can derive the benefits of the newly formed construction materials (Kamaruddin et al., 2018). FC has several advantageous properties such as low self-weight, especially for low densities, which are important in renovation operations and lowering the loads in the building's structural elements. As such, the oil palm fibres aid in reinforcing the FC and help to enhance the tensile and flexural strength of the FC.

According to Mohammadhosseini et al. (2016), the strength of EFB spikelet fibres is higher than the EFB stalk, whereas the extension at the failure of the fibre from the stalk is more than that of the fibre from the spikelet. OPT fibre was found to be suitable 
reinforcement given the high tensile strength $\left(300-600 \mathrm{~N} / \mathrm{mm}^{2}\right)$ retained by OPT, which is regarded as high compared to other natural fibres. OPT also has a high density (1200 $\left.\mathrm{kg} / \mathrm{mm}^{3}\right)$, which signifies that the fibre has a strong and high lignin content $(23.03 \%)$. Moreover, it is considered strong as lignified cellulose fibres hold their strength better than delignified fibres (Majid et al., 2012). Hence this research aims to examine the durability and mechanical properties of FC incorporating different types of biomass waste of the palm oil fibre, namely the stalk, spikelet, frond, trunk and mesocarp.

\section{MATERIALS AND METHOD}

\section{Materials}

FC is a mixture of lightweight cellular mortar and stable foam. Ordinary Portland Cement (OPC), fine sand, clean water and preformed foam are the main materials used to form FC. The cement used in this mixture is Type 1 Portland Cement under British Standard BS12 (British Standard Institution, 1996), and a portable foaming generator is used to produce the stable foam practically. In this study, a synthetic foaming agent, as the foaming agent, was used to produce the foam. This type of foaming agent is suitable to produce FC since it has a density of $1000 \mathrm{~kg} / \mathrm{m}^{3}$ and above. The ratio of foam to water applied was 1:30. This colourless liquid has a specific gravity of 1.05 and is a foaming agent containing sodium sulphate that eases foam formation. Previously, foam generators were used as a preform foaming agent and to mix the synthetic foam with water.

Next, the foam was then applied to the mortar and mixed for 5 minutes. The mixing rotation speed was subsequently decreased to prevent the occurrence of defects. The weight of the foam used in this study was $65 \mathrm{~g} /$ litre for each design mix. In addition, the fine aggregate used in this study was natural fine sand obtained through a local distributor. The fine sand had been sieved during the material preparation. The appropriate size of fine aggregates or fine sand used was $1.18 \mathrm{~mm}$ using a sieving machine according to British Standard BS882 (British Standard Institution, 1992). Clean water free from debris and other organic materials was used to mix and cure the process in this study. The water-cement ratio was 0.45 based on previous studies that claimed that this ratio could achieve reasonable workability of FC. Oil palm fibres were used in vast quantities of oil palm biomass such as oil palm trunk (OPT), an oil palm frond (OPF), oil palm mesocarp (OPM) and empty fruit bunch (EFB) consisting of the stalk and spikelets generated by the oil palm industry in Malaysia.

The OPF and OPT were produced from oil palm plantations, while the oil palm EFB was from oil palm processing. The OPM is residue attained from oil palm fruits after extracting the oil. All these fibres were extracted and processed in factories and supplied from a local supplier. The fibres were cleaned and rinsed five times using tap 
water beforehand to eliminate any unwanted debris (Figure 1). The fibres were then sun-dried for about $72 \mathrm{~h}$ until thoroughly dried. Only natural fibres were used in this study, having a length of around $3 \mathrm{~cm}$ and $0.01 \mathrm{~mm}$ in diameter. The weight fraction used was $0.45 \%$ by weight of the total mix. The chemical composition and mechanical properties of these fibres are shown in Table 1. Figure 2 visualises the SEM micrograph images of different types of fibre used in this investigation.

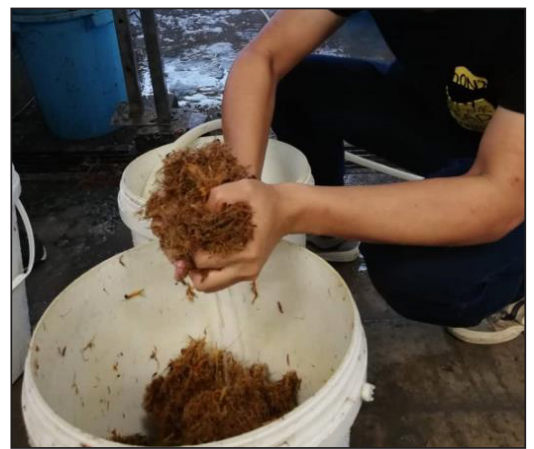

Figure 1. Fibres were properly washed to remove unwanted residue and debris

Table 1

Chemical composition and mechanical properties of fibres

\begin{tabular}{lccccc}
\hline \multicolumn{1}{c}{ Composition } & Frond fibre & Trunk fibre & Mesocarp fibre & Spikelets fibre & Stalk fibre \\
\hline Lignin $(\%)$ & $21.4 \pm 0.6$ & $20.1 \pm 0.8$ & $31.4 \pm 3.8$ & $23.6 \pm 0.5$ & $17.8 \pm 0.7$ \\
Cellulose (\%) & $31.7 \pm 4.1$ & $34.4 \pm 0.8$ & $24.5 \pm 0.7$ & $25.1 \pm 2.6$ & $33.1 \pm 0.6$ \\
Hemicellulose (\%) & $34.3 \pm 1.2$ & $14.3 \pm 1.6$ & $31.7 \pm 4.4$ & $26.2 \pm 1.5$ & $32.8 \pm 2.2$ \\
Extractives $(\%)$ & $2.5 \pm 0.4$ & $2.4 \pm 0.3$ & $4.3 \pm 0.2$ & $2.7 \pm 0.3$ & $3.2 \pm 0.4$ \\
Diameter $(\mu \mathrm{m})$ & 296 & 275 & 382 & 358 & 329 \\
Density $\left(\mathrm{kg} / \mathrm{m}^{3}\right)$ & 660 & 635 & 804 & 758 & 722 \\
Tensile strength $(\mathrm{MPa})$ & 96 & 67 & 139 & 116 & 82 \\
Young's modulus $(\mathrm{MPa})$ & 6753 & 3828 & 14367 & 10305 & 5831 \\
Elongation at break $(\%)$ & 14.4 & 17.5 & 9.6 & 11.5 & 14.7 \\
\hline
\end{tabular}

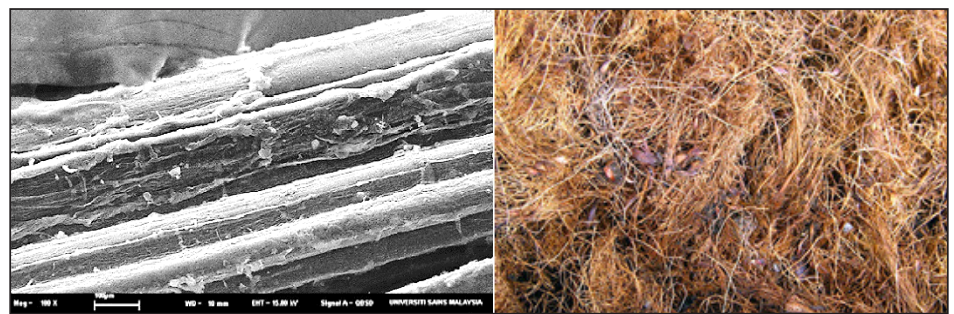

(a)

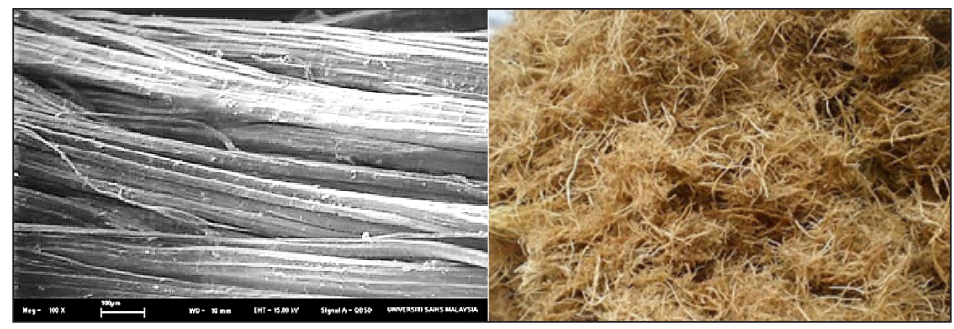

(b)

Figure 2. SEM micrograph of different types of fibre used in this study: (a) mesocarp fibre; and (b) stalk fibre 


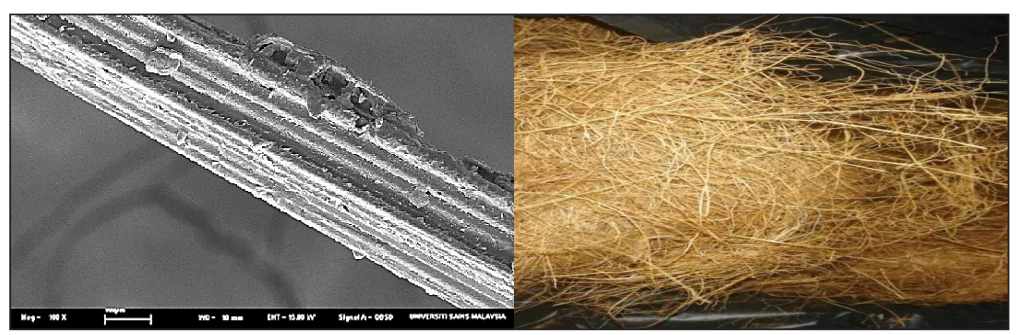

(c)

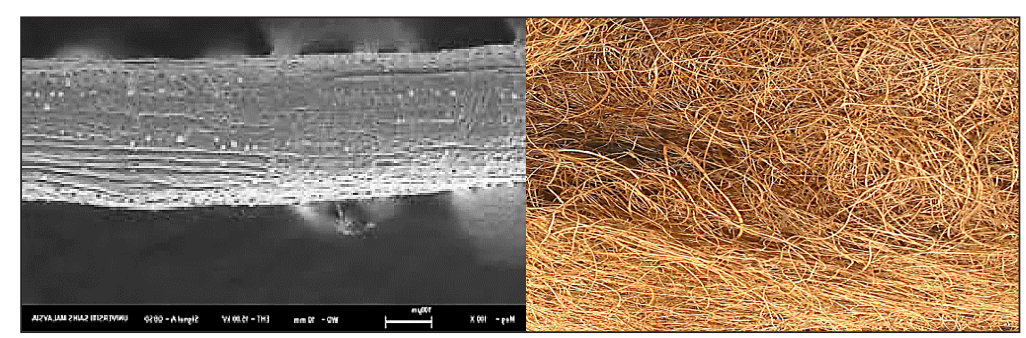

(d)

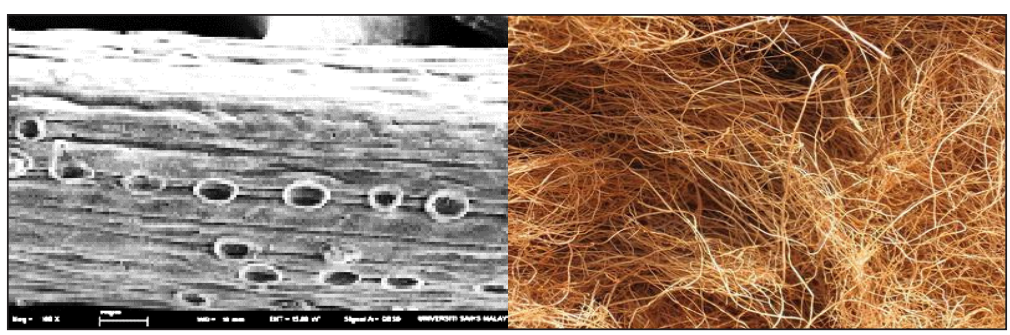

(e)

Figure 2 (continue). SEM micrograph of different types of fibre used in this study: (c) frond fibre; (d) trunk fibre; and (e) spikelets fibre

\section{Mix Design}

A total of 6 mixes were prepared in this research. The density used was kept constant at $1800 \mathrm{~kg} / \mathrm{m}^{3}$. The fibre weight fraction (weight-to-weight ratio) used in this study was $0.45 \%$. For all mixes, the sand-cement ratio was $1: 1.5$, and the water-cement ratio was kept constant at 0.45 because it gave adequate workability through the flow table test (Figure 3). The desirable spread for this flow table test is between $20-25 \mathrm{~cm}$. For this

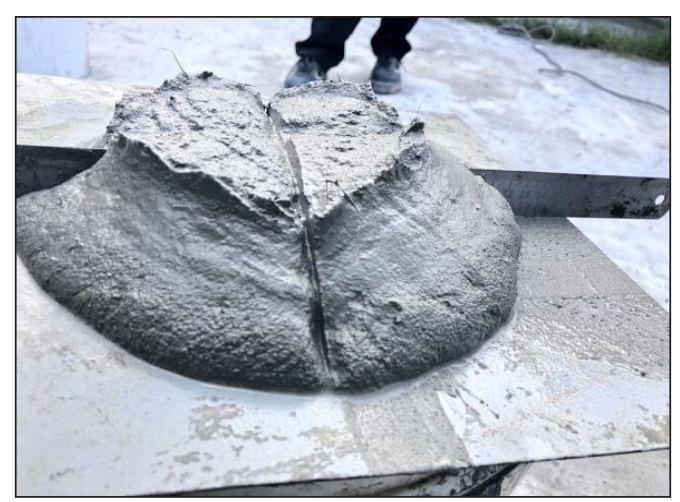

Figure 3. Flow table test assessment, spreads of 22 to $24 \mathrm{~cm}$ were achieved. Table 2 shows the proportions of the mix used in this study. 
Table 2

Mix proportions

\begin{tabular}{lcccccccc}
\hline Type & $\begin{array}{c}\text { Target } \\
\text { Density } \\
\left(\mathrm{kg} / \mathrm{m}^{3}\right)\end{array}$ & $\begin{array}{c}\text { Actual mix } \\
\text { Density } \\
\left(\mathrm{kg} / \mathrm{m}^{3}\right)\end{array}$ & $\begin{array}{c}\text { Percentage } \\
\text { of Fibre } \\
(\%)\end{array}$ & $\begin{array}{c}\text { Mix ratio } \\
(\mathrm{S}: \mathrm{C}: \mathrm{W})\end{array}$ & $\begin{array}{c}\text { Cement } \\
\text { weight } \\
(\mathrm{kg})\end{array}$ & $\begin{array}{c}\text { Fine } \\
\text { sand } \\
(\mathrm{kg})\end{array}$ & $\begin{array}{c}\text { Water } \\
(\mathrm{kg})\end{array}$ & $\begin{array}{c}\text { Fibre } \\
\text { weight } \\
(\mathrm{kg})\end{array}$ \\
\hline Control & 1800 & 1793 & - & $1: 1.5: 0.45$ & 39.81 & 59.72 & 17.92 & - \\
Frond & 1800 & 1805 & 0.45 & $1: 1.5: 0.45$ & 39.81 & 59.72 & 17.92 & 0.529 \\
Trunk & 1800 & 1799 & 0.45 & $1: 1.5: 0.45$ & 39.81 & 59.72 & 17.92 & 0.529 \\
Mesocarp & 1800 & 1813 & 0.45 & $1: 1.5: 0.45$ & 39.81 & 59.72 & 17.92 & 0.529 \\
Spikelet & 1800 & 1811 & 0.45 & $1: 1.5: 0.45$ & 39.81 & 59.72 & 17.92 & 0.529 \\
Stalk & 1800 & 1809 & 0.45 & $1: 1.5: 0.45$ & 39.81 & 59.72 & 17.92 & 0.529 \\
\hline
\end{tabular}

\section{Testing}

The tests performed in this study involved examining the durability and mechanical properties of the oil palm fibres. The water absorption test, porosity test, ultrasonic pulse velocity (UPV) test and drying shrinkage test were undertaken to examine the durability properties of FC. In addition, destructive tests that included the compression test, flexural test and splitting tensile test were also conducted in determining the mechanical properties of FC. Tables 3 and 4 show details of the specimens and standard codes of these tests for the durability properties and mechanical properties tests.

Table 3

Durability properties test

\begin{tabular}{|c|c|c|c|}
\hline Type of Test & Specimen & Code & Description \\
\hline Porosity & $\begin{array}{l}\text { Cylinder }(45 \\
\text { mm diameter } \times \\
50 \text { mm height })\end{array}$ & $\begin{array}{l}\text { British Standard } \\
\text { BS1881-122 (British } \\
\text { Standard Institution, } \\
\text { 1983) }\end{array}$ & $\begin{array}{l}\text { The specimens are fully submerged in the vacuum } \\
\text { chamber for } 48 \mathrm{~h} \text { after being removed from the } \\
\text { oven and cooled. The mass in water and mass in } \\
\text { the air is then recorded. }\end{array}$ \\
\hline $\begin{array}{l}\text { Water } \\
\text { Absorption }\end{array}$ & $\begin{array}{l}\text { Cylinder }(75 \\
\text { mm diameter } \\
\times 100 \mathrm{~mm} \\
\text { height })\end{array}$ & $\begin{array}{l}\text { British Standard } \\
\text { BS1881-122 (British } \\
\text { Standard Institution, } \\
\text { 1983) }\end{array}$ & $\begin{array}{l}\text { The specimens are placed in an oven for } 72 \mathrm{~h} \text {. } \\
\text { After being removed and cooled, specimens are } \\
\text { weighted and immediately immersed in the tank. } \\
\text { The specimens are left immersed for } 30 \text { min. } \\
\text { Then, after being removed from the water, the } \\
\text { specimens are weighed again. }\end{array}$ \\
\hline $\begin{array}{l}\text { Drying } \\
\text { Shrinkage }\end{array}$ & $\begin{array}{l}\text { Prism }(75 \mathrm{~mm} \\
\times 75 \mathrm{~mm} \times \\
275 \mathrm{~mm})\end{array}$ & $\begin{array}{l}\text { ASTM International } \\
\text { C878 (ASTM } \\
\text { International, 2014) }\end{array}$ & $\begin{array}{l}\text { A spherical gauge plugs are attached at both } \\
\text { ends of the specimens to facilitate length change } \\
\text { measurements. }\end{array}$ \\
\hline UPV & $\begin{array}{l}\text { Prism }(100 \\
\mathrm{mm} \times 100 \mathrm{~mm} \\
\times 500 \mathrm{~mm})\end{array}$ & $\begin{array}{l}\text { British Standard } \\
\text { BS12504-4 (British } \\
\text { Standard Institution, } \\
\text { 2004) }\end{array}$ & $\begin{array}{l}\text { The ultrasonic pulse velocity (UPV) is examined } \\
\text { by measuring the propagation velocity of a } \\
\text { transmitted longitudinal ultrasonic pulse across } \\
\text { the cross-sectional area. The transducers are } \\
\text { placed for testing at a length of } 0.5 \mathrm{~m} \text {. }\end{array}$ \\
\hline
\end{tabular}


Table 4

Mechanical properties test

\begin{tabular}{|c|c|c|c|}
\hline Type of Test & Specimen & Code & Description \\
\hline $\begin{array}{l}\text { Compression } \\
\text { Test }\end{array}$ & $\begin{array}{l}\text { Cube }(100 \mathrm{~mm} \\
\times 100 \mathrm{~mm} \times \\
100 \mathrm{~mm})\end{array}$ & $\begin{array}{l}\text { British Standard } \\
\text { BS12390-3 (British } \\
\text { Standard Institution, } \\
\text { 2011) }\end{array}$ & $\begin{array}{l}\text { Compressive strength test of FC is performed } \\
\text { using GoTech GT-7001-BS300 Universal Testing } \\
\text { Machine. The maximum load and compressive } \\
\text { strength are recorded. }\end{array}$ \\
\hline Flexural Test & $\begin{array}{l}\text { Prism }(100 \mathrm{~mm} \\
\times 100 \mathrm{~mm} \times \\
500 \mathrm{~mm})\end{array}$ & $\begin{array}{l}\text { ASTM International } \\
\text { C293 (ASTM } \\
\text { International, 2016) }\end{array}$ & $\begin{array}{l}\text { Flexural strength test of FC is conducted } \\
\text { using GoTech GT-7001-C10 Universal Testing } \\
\text { Machine. The maximum load and flexural } \\
\text { strength are recorded. }\end{array}$ \\
\hline $\begin{array}{l}\text { Splitting } \\
\text { Tensile Test }\end{array}$ & $\begin{array}{l}\text { Cylinder }(100 \\
\text { mm diameter } \times \\
200 \mathrm{~mm} \text { height })\end{array}$ & $\begin{array}{l}\text { ASTM International } \\
\text { C496 (ASTM } \\
\text { International, 2017) }\end{array}$ & $\begin{array}{l}\text { Tensile strength test of FC is accomplished using } \\
\text { GoTech GT-7001-BS300 Universal Testing } \\
\text { Machine. The maximum load and splitting } \\
\text { tensile strength are recorded. }\end{array}$ \\
\hline
\end{tabular}

\section{RESULTS AND DISCUSSION}

\section{Water Absorption}

The water absorption percentage in FC specimens is shown in Figure 4. It is seen that the mesocarp fibre results had the lowest percentage of water absorption at $7.94 \%$, followed by the percentage of the water absorption of the spikelet fibre at $7.99 \%$. It shows a slight difference between spikelet fibre and mesocarp fibre at $0.05 \%$. The control mix resulted in the highest rate of water absorption of $9.18 \%$. Among all five fibres considered in this study, trunk fibre led to the highest water absorption capacity of FC (9.09\%). These results can be related to the chemical composition of the fibre itself. With reference to Table 1, the percentage of cellulose will directly affect the water absorption of fibre reinforced FC. For instance, the cellulose content in trunk fibre is the highest (34.4\%), while cellulose content in mesocarp fibre is the lowest (24.5\%). Fibre with high cellulose content has a greater diffusion coefficient and transport capacity; thus, it absorbs more water. Additionally, according to Elrahman et al. (2019), water absorption is highly dependent on the voids in the composite itself; the water fills the empty voids quickly by capillary action until the voids are limited. However, with the addition of oil palm fibres, the water absorption in FC can be reduced compared to the control specimens without fibre. Fu et al. (2020) concurred that as fibre content increases, water absorption would increase. This proposition is also supported by Hamad (2014) that water absorption increases as the fibre content increases.

Therefore, in this research, the percentage of fibre content is held constant at $0.45 \%$, the optimum percentage that allows good water absorption in FC. On the other hand, moisture diffusion occurs by transmitting fluid molecules through the porous structure, although this process is inhibited by the required number of fibres that fill up the void in the FC matrix. However, an abundant amount of fibre may cause capillary transport into the gaps and flaws at the interface between the fibre and matrix (Jalal et al., 2017). 
During this process, the effect of water begins with the swelling of the fibre after moisture absorption continues with the matrix micro-crack around the swollen fibres. Then, the capillary mechanism, water molecules flow along with the fibre-matrix interface, causing water diffusion through the bulk matrix. Finally, the water-soluble substances leach from the fibres, causing ultimate fibre-matrix debonding. It may result in a reduction of the mechanical properties of the concrete.

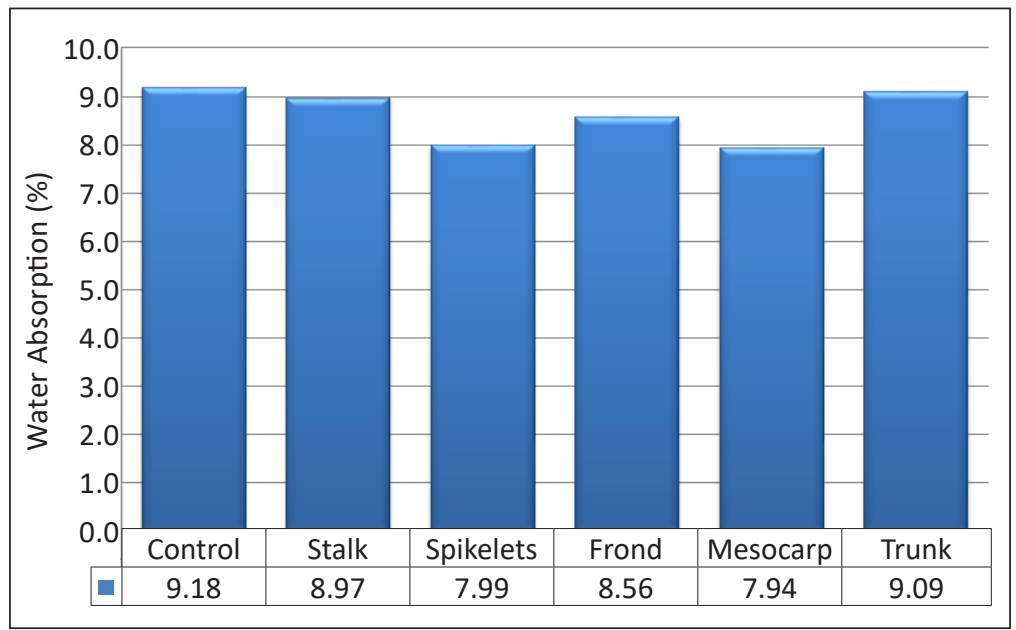

Figure 4. Influence of different parts of oil palm fibre on water absorption of $1800 \mathrm{~kg} / \mathrm{m}^{3}$ density FC

\section{Porosity}

Figure 5 shows the result for the percentage of porosity in FC. Based on this result, FC, including all parts of oil palm fibre, resulted in a lower porosity percentage than the control mix. According to Lim et al. (2013), porosity and pore size distribution in FC may be reduced by using admixtures. Therefore, the inclusion of oil palm fibres helped to initiate blocked pore structures to reduce the diameter of openings and reduce the permeability of the concrete structure. Thus, it can be concluded that the inclusion of fibre can reduce porosity in FC. With reference to Figure 5, the control specimen recorded the highest porosity of $25.91 \%$. The addition of mesocarp fibre gave the lowest porosity of $22.45 \%$, while trunk fibre inclusion led to the highest porosity reading of $24.78 \%$. Same as water absorption, the cellulose content in fibre plays an important role and affects the porosity of FC. When the oil palm fibres were exposed to a process of water absorption, this cellulose swelled. As a result of the swelling, microcracks can appear in a brittle matrix in the cementitious composite of FC, leading to the largest transport of water through the fibre matrix interface and giving high porosity. The formation of microcracks if FC matrix at the interface region, induced by cellulose fibre swelling, can upsurge the diffusion transference of water via them. Additionally, a capillarity mechanism becomes active; water molecules flow through the fibre and FC matrix interface, leading to a greater diffusivity. The difference 
of diffusion coefficient values for the same fibre weight fraction in FC can be explained again due to the scattering of natural constituents of the fibre itself.

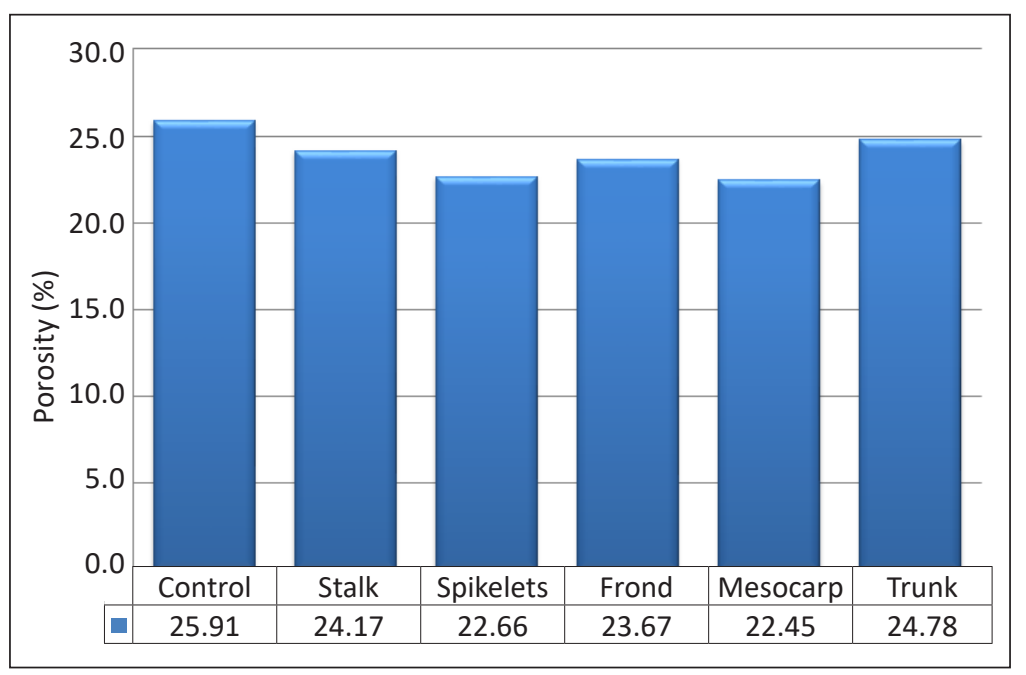

Figure 5. Influence of different parts of oil palm fibre on porosity of $1800 \mathrm{~kg} / \mathrm{m}^{3}$ density FC

\section{Ultrasonic Pulse Velocity}

Based on the result shown in Figure 6 below, the highest reading of the UPV is influenced by the mesocarp fibre. A UPV test was conducted to determine the quality of concrete. From Figure 6, the ultrasonic pulse velocity result with the addition of mesocarp fibre was the highest $(3217 \mathrm{~m} / \mathrm{s})$, followed by spikelets $(3208 \mathrm{~m} / \mathrm{s})$, stalk $(2995 \mathrm{~m} / \mathrm{s})$, frond $(2966 \mathrm{~m} / \mathrm{s})$ and lastly, the trunk fibre $(2945 \mathrm{~m} / \mathrm{s})$. The control mix only achieved ultrasonic pulse velocity reading of $2894 \mathrm{~m} / \mathrm{s}$. According to Moon et al. (2015), concrete with a UPV value between $3500-4000 \mathrm{~km} / \mathrm{s}$ is in the range reflecting good to a perfect type of concrete; thus, FC with the addition of mesocarp fibre is categorised as good and of a high-quality concrete grade. It shows that the control mix is considered a poor quality of concrete. Therefore, the inclusion of fibre can enhance the quality of concrete. The UPV allows the examination of material homogeneity and ease in the diagnosis of defects. It also allows for examining material homogeneity and ease in the diagnosis of defects. The UPV method is when the material passes through the propagation of a high-frequency sound wave. Wave speed varies according to material density allowing for porosity estimation and discontinuity detection. The quality of most building materials is related to their rigidity. The measurement of UPV can be used to measure concrete structures' quality, estimate the mechanical properties, compressive strength and modulus of elasticity.

The ultrasonic pulse velocity results obtained from this experimental work can be linked with the cross-section diameter of the fibres themselves. The cross-section diameter of fibre in harden cement matrix will influence the ultrasonic pulse velocity of FC. Individual 
cells in fibre cross-sections of larger diameter will fill the gaps well between the void cells of FC and led to a denser cementitious composite, which at the same time improved the ultrasonic pulse velocity of FC (Mydin \& Mohd Zamzani, 2018). The inclusion of natural fibres contributes to the modification of the pore structure of FC, leading to reduced gel pores in FC. Among the five types of oil palm fibre considered in this research, mesocarp fibre has the largest cross-section diameter of $382 \mu \mathrm{m}$, followed by spikelets fibre $(358 \mu \mathrm{m})$, stalk fibre $(329 \mu \mathrm{m})$, frond fibre $(296 \mu \mathrm{m})$ and trunk fibre $(275 \mu \mathrm{m})$. So, it can be seen that the larger the diameter of the fibre, the better will be the result of the ultrasonic pulse velocity. Natural fibre like oil palm is flexible and small in diameter. Intrinsically, they create a small matrix of aggregates within the larger FC matrix. If ultrasonic pulse flows through FC via the cement paste, the fibres create a more tortuous path. The more tortuous the path, the longer it takes for the ultrasonic pulse to traverse through it.

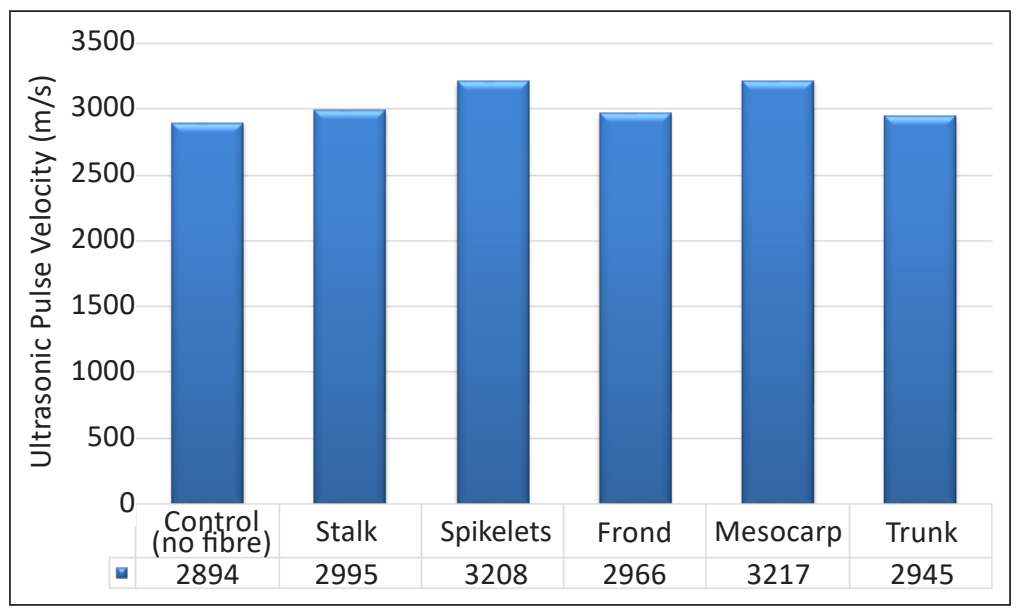

Figure 6. Influence of different parts of oil palm fibre on UPV of $1800 \mathrm{~kg} / \mathrm{m}^{3}$ density FC

\section{Drying Shrinkage}

Figure 7 shows the result of the drying shrinkage for FC with a density of $1800 \mathrm{~kg} / \mathrm{m}^{3}$ and different parts of oil palm fibre. The drying shrinkage of FC with mesocarp fibre increased significantly until day 28 of the testing age. On day 28, the drying shrinkage of this mixture exceeds the drying shrinkage that occurs in the FC with the inclusion of spikelet fibre. It can be seen from Figure 7 that all drying shrinkage in the FC with the inclusion of oil palm fibres slightly increases after day 28 until day 60. It is due to the concrete specimens' condition during the first seven days, which were not fully hardened, while on day 28 onwards, the concrete specimens hardened completely, thus slowing the shrinkage in the concrete (Tangchirapat \& Jaturapitakkul, 2010). Based on Figure 7, the control mix experienced the highest drying shrinkage in the FC. The absence of solid aggregate in FC makes the particles in FC become closer with the evaporation of water; hence, it increases the shrinkage value of the FC. 
However, with the addition of oil palm fibres, drying shrinkage in FC can be reduced. Previous studies proved that the inclusion of fibre restricts drying shrinkage. According to Munir et al. (2015), fibre can retain water, thus delaying the water evaporation rate and reducing drying shrinkage. From Figure 4, spikelets and mesocarp fibres gave the best result in terms of drying shrinkage. Spikelets and mesocarp fibres have excellent young's modulus and elongation at break (Table 1). Elongation at break of mesocarp fibre was only $9.6 \%$ and for mesocarp fibre was $11.5 \%$. The other fibres got higher elongation at break. For instance, elongation at break of trunk fibre was $17.5 \%$, almost double that of mesocarp fibre. Therefore, fibre with lower elongation at break percentage will not shrink much when combined with FC cementitious material.

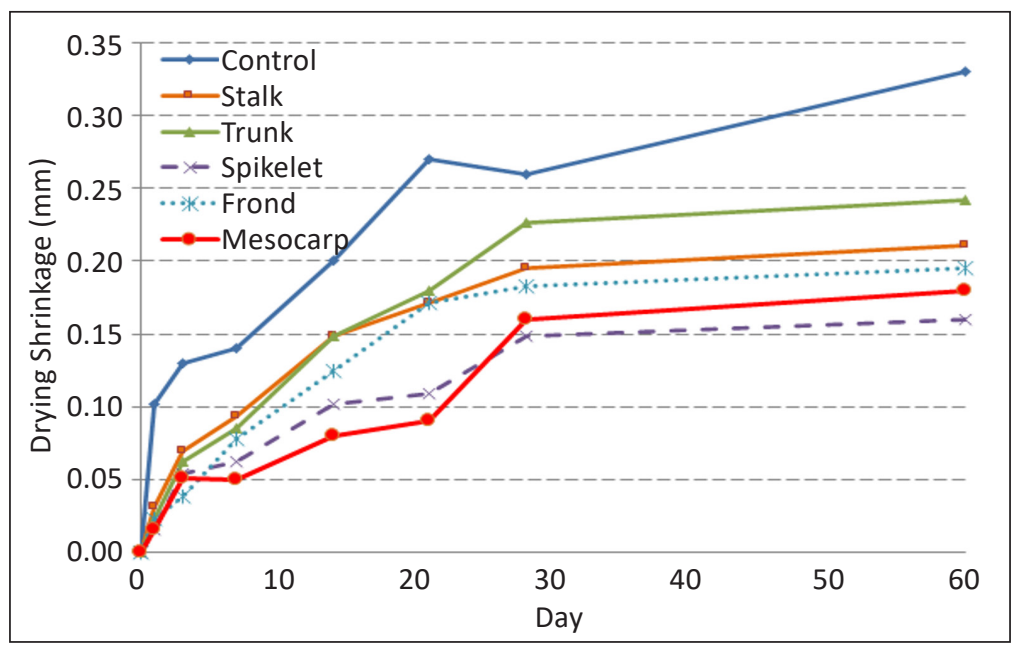

Figure 7. Influence of different parts of oil palm fibre on drying shrinkage of $1800 \mathrm{~kg} / \mathrm{m}^{3}$ density FC

\section{Compressive Strength}

The result of the compressive strength of FC with the addition of oil palm fibres is shown in Figure 8, where there is a noticeable improvement in the compressive strength of FC beginning from day seven until day 60 of the testing age. It can be seen that FC, without the addition of oil palm fibre, has the lowest compressive strength compared to other mixtures. With the addition of mesocarp fibre, FC achieved the highest compressive strength of $30 \%$ increment compared to the control specimen at day 28 , followed by FC with the addition of spikelet fibre (21\% increment). Besides, there is also a noticeable increase in compressive strength at $16 \%, 11 \%$ and $7 \%$ of the FC specimens, including the frond, stalk, and trunk, respectively, at day 28 . Here, the fibres and the cement matrix achieved high compaction, which resulted in good mix homogeneity with $0.45 \%$ fibre inclusion. This finding is also supported by Muthusamy \& Zamri (2016), who proved that compressive strength and bulk density are slightly enhanced with low fibre content ranging between $0.3 \%$ to $1.5 \%$. 
These results were expected to be related to the young's modulus of the fibres. Mesocarp fibre has the highest young's modulus, $14367 \mathrm{MPa}$, compared to other fibres from oil palm biomass waste. When relating to the single fibre test results in Table 1, mesocarp fibre has the highest value of young's which was $14367 \mathrm{MPa}$, followed by spikelet (10305 MPa), frond $(6753 \mathrm{MPa})$, stalk (5831 MPa) and trunk (3828 MPa), thus directly contributing to the higher compressive strength of foamed concrete. By adding mesocarp fibre which has the highest young's modulus in FC, the resistance of the composite has been suppressed. This result may be explained because fibre with higher young's modulus provides greater rigidity to the $\mathrm{FC}$ matrix.

However, if the fibre content exceeds $0.5 \%$, the compressive strength of mortar samples is reduced, as proven by other studies. According to Mydin et al. (2016a), the high addition of fibre into the concrete mixture will retard the hydration process, thus resulting in low strength concrete. Although it also gains strength after a certain concrete age. As FC contains void gaps of a wide range of sizes and shapes in the matrix and micro-cracks at the transition zone between the matrix, the addition of fibre can aid in the failure of the mode under compression stress (Thakrele, 2014). Therefore, based on the result obtained in this study, it can be concluded that all FC mixes undergo strength development based on age.

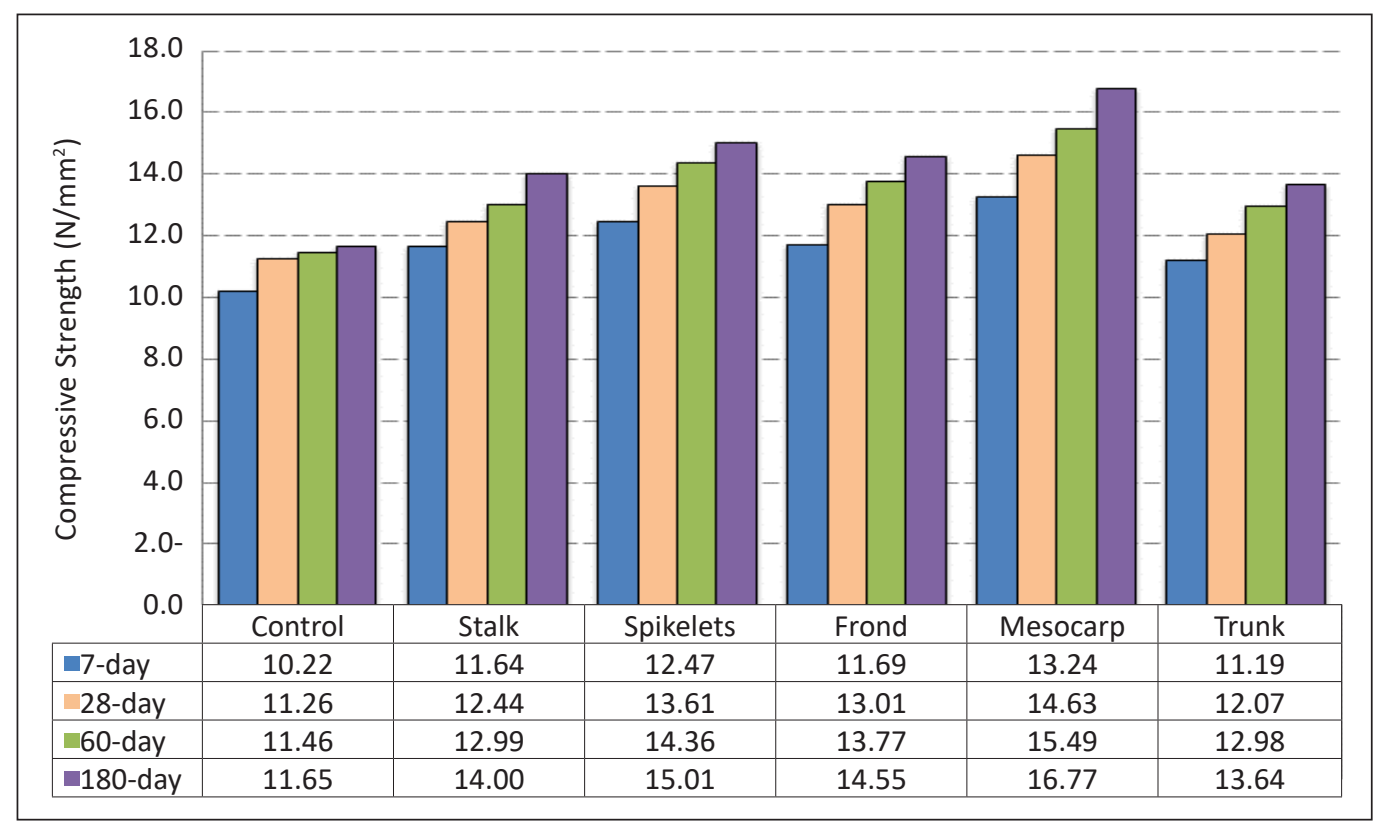

Figure 8. Influence of different parts of oil palm fibre on axial compressive strength of $1800 \mathrm{~kg} / \mathrm{m}^{3}$ density FC

\section{Flexural Strength}

Figure 9 shows the result of the FC specimens' flexural strength with oil palm fibre. The FC specimens with the inclusion of mesocarp fibre show the highest floral strength compared to the other mixtures. The control mix obtained the lowest flexural strength showing only 
a slight increment along with the testing age. However, FC specimens with the addition of oil palm fibres show a significant increment in flexural strength by age. Moreover, there is a noticeable increase of compressive strength at $41 \%, 74 \%, 67 \%$ and $37 \%$ of the FC specimens, including stalk fibre, spikelet fibre, frond fibre and trunk fibre, respectively, at day 28 compared to control specimen. The highest flexural strength at day 28 was achieved with the inclusion of mesocarp fibre with an enhancement of $96 \%$ compared to the control specimen.

These results were likely to be related to the tensile strength of the fibres presented in Table 1. Mesocarp fibre has the highest tensile strength, $139 \mathrm{MPa}$, among other fibres from oil palm biomass waste considered in this research. The tensile strength of a single fibre is defined as the ability of the fibre to resist a force that tends to pull it apart. So, the stronger fibre entanglement such as mesocarp fibre will sturdily keep the fibres together and create tougher fibre-matrix adhesion, which leads to excellent flexural strength properties to the FC specimens under the applied load. Meanwhile, trunk fibre has the lowest tensile strength (67 MPa), followed by a stalk (82 MPa), frond (96 MPa) and spikelet (116 MPa). This relatively low transverse stiffness of fibre creates weak planes of failure for a much stiffer matrix, thus exhibiting the lowest percentage of flexural strength enhancement. Hence, the results obtained increases the possibility that mesocarp fibre is the most effective fibre that can provide stronger fibre gripping in a longer period, thus delaying fracture in composites at early of day seven under flexural.

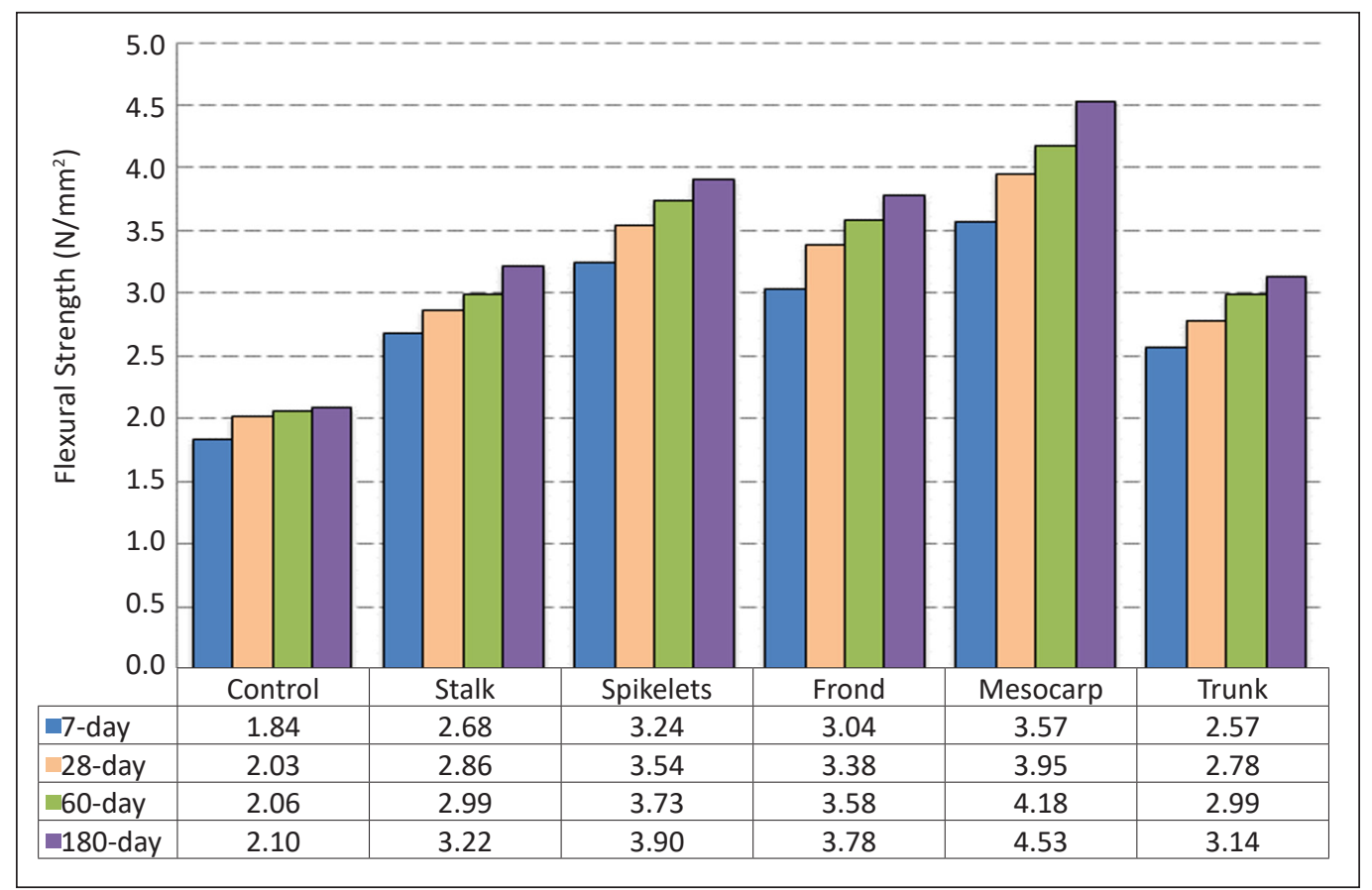

Figure 9. Influence of different parts of oil palm fibre on the flexural strength of $1800 \mathrm{~kg} / \mathrm{m}^{3}$ density FC 
Ramamurthy et al. (2009) reported that the flexural strength of FC ranges between $15 \%$ and $35 \%$ of its compressive strength. Whereas in the current research, the flexural strength of FC is between $20-28 \%$ of its compressive strength. The fibre in FC is to strengthen FC mass and transfer the basic material character from brittle to ductile elastic-plastic. Fibre contributes towards enhancing the flexural strength of FC. However, excessive fibre content may also reduce bonding and deterioration (Mydin et al., 2016b). The use of a $0.45 \%$ volumetric fraction of fibre content can be considered an optimal percentage for this type of concrete based on the increment of compressive strength and flexural strength. The increase of flexural strength is compatible with the compressive strength increase. High flexural strength is due to reducing porosity in FC mixes (Sari \& Sani, 2017). Therefore, based on the result of the strength obtained, it can be concluded that the inclusion of fibre can enhance flexural strength by age.

\section{Splitting Tensile Strength}

Figure 10 displays the trend of increasing splitting tensile strength in FC, including different parts of oil palm fibre. Based on the result, the FC specimens with mesocarp fibre achieved the highest tensile strength, whereas the control mix obtained the lowest tensile strength. As for the other specimens, each mix achieved a noticeable increment in tensile strength at $22 \%, 20 \%, 20 \%$ and $18 \%$ of FC with the addition of stalk fibre, spikelet fibre, frond fibre and trunk fibre, respectively.

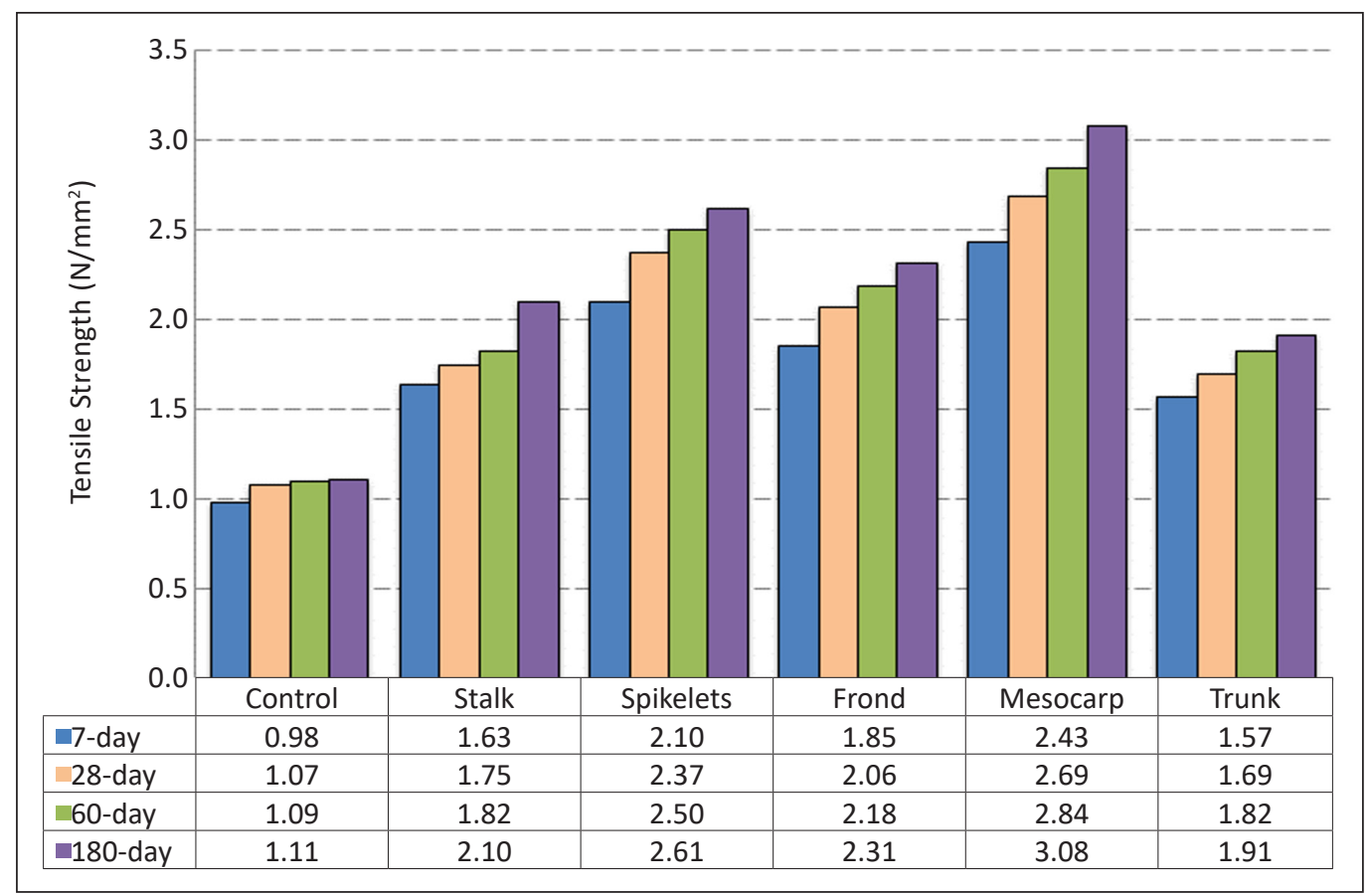

Figure 10. Influence of different parts of oil palm fibre on the tensile strength of $1800 \mathrm{~kg} / \mathrm{m}^{3}$ density FC 
In this research, the splitting tensile strength of FC is $60 \%$ of its flexural strength. As shown in Table 1, the elongation at break for mesocarp fibre is low, resulting in high tensile strength (Müller et al., 2014). Elongation at break expresses the ability of fibre to resist changes of shape without crack formation. Natural fibre such as oil palm fibre is more rigid, thus enhancing the splitting tensile strength (Memon et al., 2018). FC is known to have low tensile strength and brittle nature. However, based on the data recorded in this study, the tensile strength was shown to increase due to oil palm fibres slightly. The increase of tensile strength is due to the increase in toughness of concrete due to the presence of oil palm fibres, where $0.45 \%$ of fibre content enhances the increment of tensile strength in FC by promoting optimum pozzolanic reaction with OPC content, thus producing denser and stronger concrete. The data obtained in this study indicate that the addition of oil palm fibres enhances the tensile strength of FC.

\section{Correlation Between Water Absorption and Porosity}

As shown in Figure 11 below, the relationship between the two variables is almost linear. It shows that lower density mixtures absorb significantly higher percentages of water compared to those with higher densities. According to Jhatial et al. (2017), water absorption can be expressed as either an increase in mass per unit of dry mass or an increase per unit volume. In normal concrete, water absorption results are most likely to be relatively similar, no matter how they are expressed. However, in FC mixtures, there will be a remarkable contrast if expressed by both expressions. The researchers also claimed that FC mixtures with high porosity do not necessarily result in high-water absorption. Kim et al. (2010) also agreed that there was no clear relationship between water absorption and porosity. However, a linear correlation exists between them. The pore structure of the cement

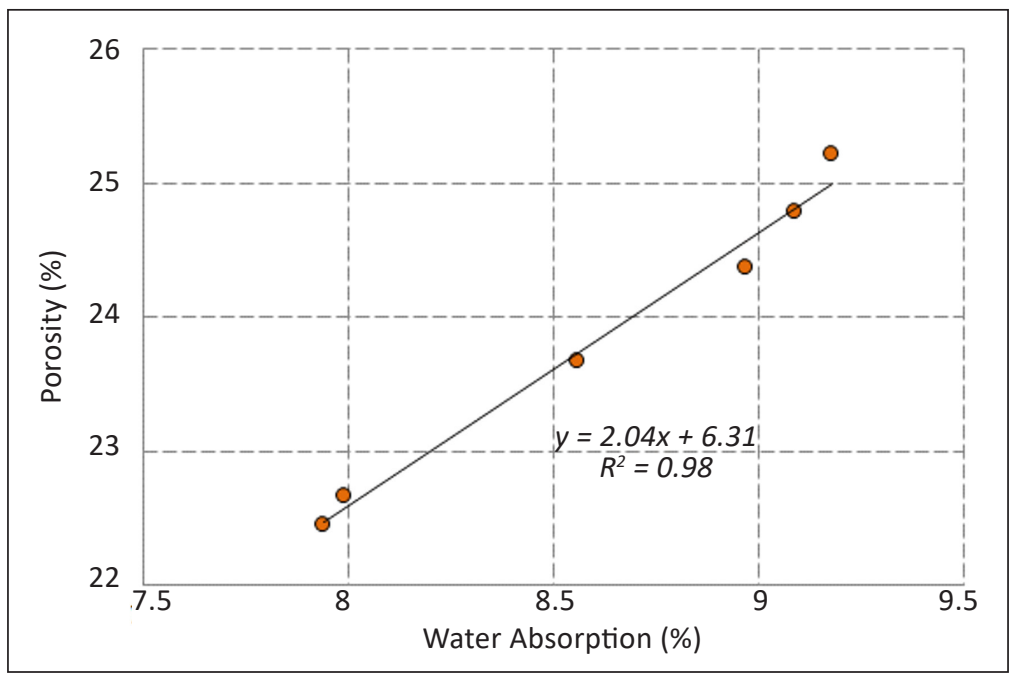

Figure 11. Correlation between water absorption and porosity of $1800 \mathrm{~kg} / \mathrm{m}^{3}$ density FC 
matrix affects both water absorption and porosity. The distribution of liquid occurs at the surface and flows into the interior. Therefore, this proves that surface water absorption has a significant influence on porosity. In addition, internal water absorption may have little impact on the porosity of FC.

\section{Correlation Between Compressive Strength and Porosity}

Air voids, capillary pores and gel pores are conditions found in the pore structure of cementbased materials, in which the pores are randomly sized, organised and attached. Porosity is recognised as one of the major elements that directly affect the strength and durability of cement-based materials. Based on Figure 12, it can be observed that the lower porosity of concretes with sufficient binding material content leads to a higher strength of concretes.

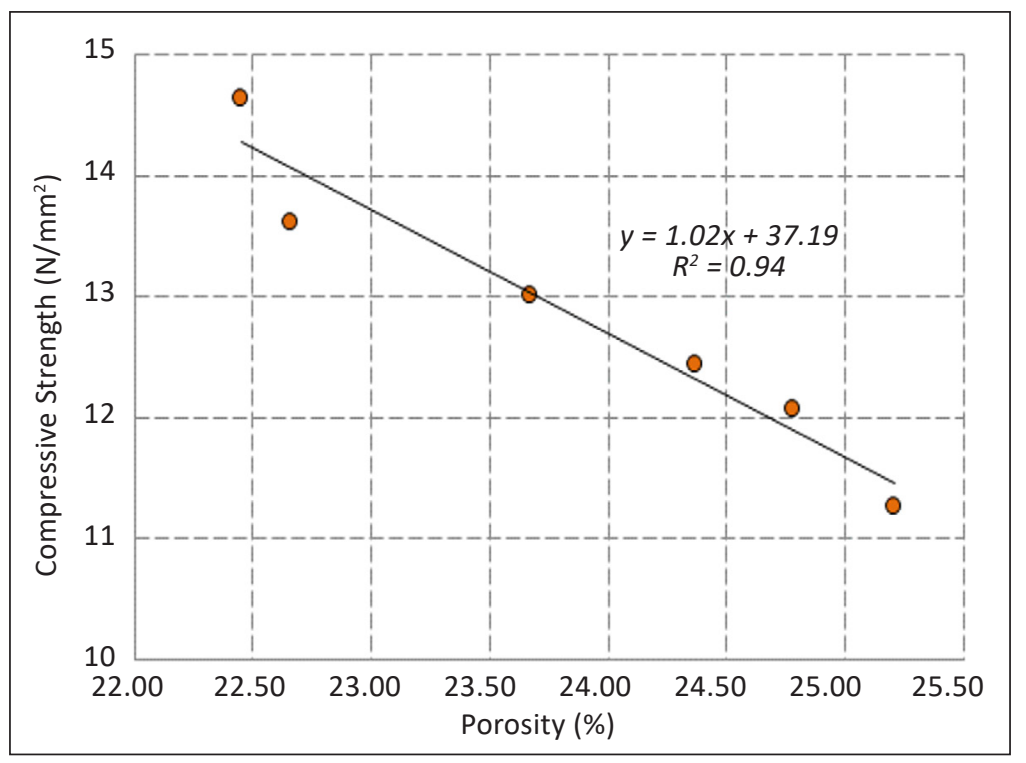

Figure 12. Correlation between compressive strength and porosity of $1800 \mathrm{~kg} / \mathrm{m}^{3}$ density FC

\section{Correlation Between Flexural Strength and Water Absorption}

The relationship between flexural strength and porosity is shown in Figure 13 below, where the behaviour of flexural strength is similar to compressive strength. As water absorption increases, flexural strength will decrease. The development of molecules that retaliate and dismantle their chemical stability is the result of high-water absorption. A product consisting of solid and pore systems is obtained through the hydration reaction of cement (Jalal et al., 2017). The pathway for the transfer of fluid into concrete is supplied by opening the network of the cement paste matrix, and its development depends on several considerations, such as the initial condition and its duration, testing age and climatic exposure during drying and conditioning of concrete (Kamaruddin et al., 2018). 


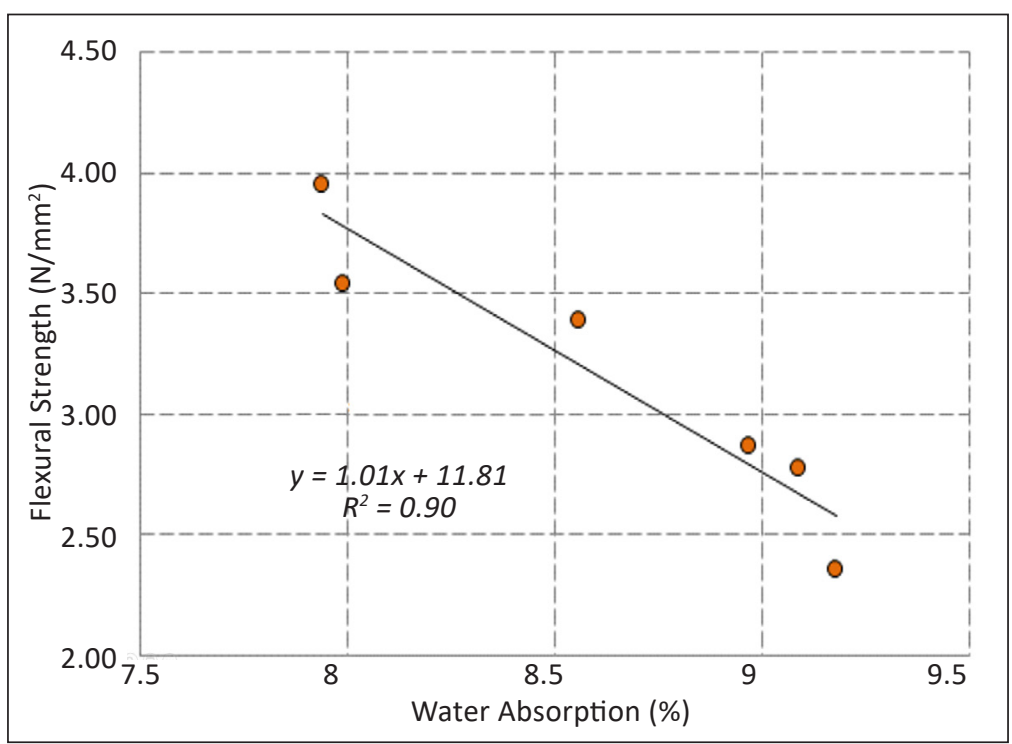

Figure 13. Correlation between flexural strength and water absorption of $1800 \mathrm{~kg} / \mathrm{m}^{3}$ density FC

\section{CONCLUSION}

In this research, with mesocarp fibre, FC attained remarkable results, which proved that the addition of fibre in FC could enhance its properties. FC with mesocarp fibre acquired the lowest water absorption percentage at $7.94 \%$, followed by the percentage of water absorption in spikelet fibre at $7.99 \%$. It shows slight differences between spikelet fibre and mesocarp fibre at $0.05 \%$. For porosity, FC, including all parts of oil palm fibre, resulted in a lower porosity percentage than the control mix. The inclusion of oil palm fibres helps to initiate occluded opening structures to minimise the diameter of openings and reduce permeability through the concrete structure. The highest reading of UPV was influenced by mesocarp fibre. A UPV test was conducted to evaluate the quality of concrete where the FC with the addition of mesocarp fibre was categorised as a good and high-quality concrete grade with a reading of $3.217 \mathrm{~km} / \mathrm{s}$. Drying shrinkage of FC with the addition of mesocarp fibre increased significantly until day 28 of the testing age. The drying shrinkage of FC with the inclusion of oil palm fibres slightly increased after day 28 until day 60. In addition, the FC without the addition of oil palm fibre had the lowest compressive strength compared to the other mixtures. With the addition of mesocarp fibre FC achieved the highest compressive strength, followed by FC with spikelet fibre. Here, the fibres and the cement matrix were expected to achieve high compaction, leading to good homogeneity in the mixture with $0.45 \%$ fibre inclusion. The addition of fibre in FC strengthens FC mass and modifies the basic material character from fragile to ductile elastic-plastic. As such, the addition of fibre contributes to enhancing the flexural strength of FC. However, excessive fibre content may lead to reduce bonding and disintegration. 


\section{ACKNOWLEDGEMENT}

The author gratefully acknowledges financial support for this research provided by Universiti Sains Malaysia under Bridging Grant (Ref. No. 304/PPBGN/6316230).

\section{REFERENCES}

ASTM International. (2014). ASTM C878 / C878M-14a: 2014. Standard test method for restrained expansion of shrinkage-compensating concrete. ASTM International

ASTM International. (2016). ASTM C293 / C293M-16: 2016. Standard test method for flexural strength of concrete (using simple beam with center-point loading). ASTM International.

ASTM International. (2017). ASTM C496 / C496M-17: 2017. Standard test method for splitting tensile strength of cylindrical concrete specimens. ASTM International.

British Standard Institution. (1983). BS 1881-122: 1983. Testing concrete. Method for determination of water absorption. British Standards Institute.

British Standard Institution. (1992). BS 882: 1992. Specification for aggregates from natural sources for concrete. British Standards Institute.

British Standard Institution. (1996). BS 12: 1996. Specification for Portland cement. British Standards Institute.

British Standard Institution. (2004). BS 12504-4: 2004. Testing concrete. Determination of ultrasonic pulse velocity. British Standards Institute.

British Standard Institution. (2011). BS 12390-3: 2011. Testing hardened concrete. Compressive strength of test specimens. British Standards Institute.

Elrahman, M. A., El Madawy, M. E., Chung, S. Y., Sikora, P., \& Stephan, D. (2019). Preparation and characterization of ultra-lightweight foamed concrete incorporating lightweight aggregates. Applied Sciences, 9(7), 1-12. https://doi.org/10.3390/app9071447

Ezerskiy, V., Kuznetsova, N. V., \& Seleznev, A. D. (2018). Evaluation of the use of the CBPB production waste products for cement composites. Construction and Building Materials, 190(30), 1117-1123. https://doi. org/10.1016/j.conbuildmat.2018.09.148

Ferreira, S. R., De Andrade, S. F., Lima, P. R. L., \& Filho, R. D. T. (2017). Effect of hornification on the structure, tensile behavior and fiber matrix bond of sisal, jute and curaua' fiber cement based composite systems. Construction and Building Materials, 139, 551-561. https://doi.org/10.1016/j.conbuildmat.2016.10.004

Fu, Y., Wang, X., Wang, L., \& Li, Y. (2020). Foam concrete: A state-of-the-art and state-of-the-art practice review. Advances in Materials Science and Engineering, 2020, Article 6153602. https://doi. org/10.1155/2020/6153602

Hamad, A. J. (2014). Materials, production, properties and application of aerated lightweight concrete. International Journal of Materials Science and Engineering, 2(2), 152-157. https://doi.org/10.12720/ ijmse.2.2.152-157 
Hasan, K. M. F., Horvath, P. G., \& Alpar, T. (2020). Potential natural fiber polymeric nanobiocomposites: A review. Polymers, 12(5), Article 1072. https://doi.org/10.3390/polym12051072

Hasan, K. M. F., Horvath, P. G., \& Alpar, T. (2021). Lignocellulosic fiber cement compatibility: A state-of-theart review. Journal of Natural Fibers, 1-26 https://doi.org/10.1080/15440478.2021.1875380

Hospodarova, V., Singovszka, E., \& Stevulova, N. (2018). Characterization of cellulosic fibers by FTIR spectroscopy for their further implementation to building materials. American Journal of Analytical Chemistry, 9(6), 303-310. https://doi.org/10.4236/ajac.2018.96023

Jalal, M. D., Tanveer, A., Jagdeesh, K., \& Ahmed, F. (2017). Foam concrete. International Journal of Civil Engineering Research, 8(1), 1-14.

Jhatial, A. A., Inn, G. W., Mohamad, N., Alengaram, U. J., Mo, K. H., \& Abdullah, R. (2017). Influence of polypropylene fibres on the tensile strength and thermal properties of various densities of foamed concrete. In IOP Conference Series: Materials Science and Engineering (Vol. 271, No. 1, p. 012058). IOP Publishing. https://doi.org/10.1088/1757-899X/271/1/012058

Kamaruddin, S., Goh, W. I., Jhatial, A. A., \& Lakhiar, M. T. (2018). Chemical and fresh state properties of foamed concrete incorporating palm oil fuel ash and eggshell ash as cement replacement. International Journal of Engineering \& Technology, 7(4.30), 350-354. https://doi.org/10.14419/ijet.v7i4.30.22307

Karade, S., \& Aggarwal, L. (2011). Cement-bonded lignocellulosic composites for building applications. Metals Materials and Processes, 17(2), 129-140. https://10.1016/j.conbuildmat.2010.02.003

Kim, Y., Jiong, H., Jae, L., \& Heeyou, B. (2010). Mechanical properties of fiber reinforced lightweight concrete containing surfactant. Advances in Civil Engineering, 10, 1-9. https://doi.org/10.1155/2010/549642

Kochova, K., Gauvin, F., Schollbach, K., \& Brouwers, H. (2020). Using alternative waste coir fibres as a reinforcement in cement fibre composites. Construction and Building Materials, 231, Article 117121. https:// doi.org/10.1016/j.conbuildmat.2019.117121

Li, Q., Ibrahim, L., Zhou, W., Zhang, M., Fernando, G. F., Wang, L., \& Yuan, Z. (2020). Holistic solution to natural fiber deterioration in cement composite using hybrid treatments. Cellulose, 27(7), 981-989. https:// doi.org/10.1007/s10570-019-02813-2

Lim, S. K., Tan, C. S., Lim, O. Y., \& Lee, Y. L. (2013). Fresh and hardened properties of lightweight foamed concrete with palm oil fuel ash as filler. Construction and Building Materials, 46, 39-47. https://doi. org/10.1016/j.conbuildmat.2013.04.015

Mahmud, S., Hasan, K. M. F., Jahid, M. A., Mohiuddin, K., Zhang, R., \& Zhu, J. (2021). Comprehensive review on plant-fiber reinforced polymeric biocomposites. Journal of Materials Science, 56, 7231-7264. https://doi.org/10.1007/s10853-021-05774-9

Mahzabin M. S., Hock, L. J., Hossain, M. S., \& Kang, L. S. (2018). The influence of addition of treated kenaf fibre in the production and properties of fibre reinforced foamed composite. Construction and Building Materials, 178, 518-528. https://doi.org/10.1016/j.conbuildmat.2018.05.169

Majid, A., Anthony, L., Hou, S., \& Nawawi, C. (2012). Mechanical and dynamic properties of coconut fibre reinforced concrete. Construction and Building Materials, 30, 814-825. https://doi.org/10.1016/j. conbuildmat.2011.12.068 
Memon, I. A., Jhatial, A. A., Sohu, S., Lakhiar, M. T., \& Hussain, Z. (2018). Influence of fibre length on the behaviour of polypropylene fibre reinforced cement concrete. Civil Engineering Journal, 4(9), 2124-2131. https://doi.org/10.28991/cej-03091144

Mohammadhosseini, H., Awal, A. S. M. A., \& Sam, A. R. M. (2016). Mechanical and thermal properties of prepacked aggregate concrete incorporating palm oil fuel ash. Sadhana, 41(10), 1235-1244. https://doi. org/10.1007/s12046-016-0549-9

Momeen, M., Islam, U., Mo, K. H., \& Alengaram, U. J. (2016). Durability properties of sustainable concrete containing high volume palm oil waste materials. Journal of Cleaner Production, 137, 167-177. https:// doi.org/10.1016/j.jclepro.2016.07.061

Moon, A. S., Varghese, V., \& Waghmare, S. S. (2015). Foam concrete as a green building material. International Journal for Research in Emerging Science and Technology, 2(9), 25-32.

Müller, H. S., Breiner, R., Moffatt, J. S., \& Haist, M. (2014). Design and properties of sustainable concrete. Procedia Engineering, 95, 290-304. https://doi.org/10.1016/j.proeng.2014.12.189

Munir, A., Abdullah, Huzaim, Sofyan, Irfandi, \& Safwan. (2015). Utilization of palm oil fuel ash (POFA) in producing lightweight foamed concrete for non-structural building material. Procedia Engineering, 125, 739-746. https://doi.org/10.1016/j.proeng.2015.11.119

Muthusamy, K., \& Zamri, N. A. (2016). Mechanical properties of oil palm shell lightweight aggregate concrete containing palm oil fuel ash as partial cement replacement. KSCE Journal of Civil Engineering, 20(4), 1473-1481. https://doi.org/10.1007/s12205-015-1104-7

Mydin, M. A. O., \& Zamzani, N. (2018). Coconut fiber strengthen high performance concrete: Young's modulus, ultrasonic pulse velocity and ductility properties. International Journal of Engineering \& Technology, 7(2), 284-287. https://doi.org/10.14419/ijet.v7i2.23.11933

Mydin, M. A. O., Musa, M., \& Ghani, A. N. A. (2016a). Fiber glass strip laminates strengthened lightweight foamed concrete: Performance index, failure modes and microscopy analysis. In AIP Conference Proceedings (Vol. 2016, No. 1, p. 020111). AIP Publishing LLC. https://doi.org/10.1063/1.5055513

Mydin, M. A. O., Noordin, N. M., Utaberta, N., Yunos, M. Y. M., \& Segeranazan, S. (2016b). Physical properties of foamed concrete incorporating coconut fibre. Jurnal Teknologi, 78(5), 99-105. https://doi. org/10.11113/jt.v78.8250

Onuaguluchi, O., \& Banthia, N. (2016). Plant-based natural fibre reinforced cement composites: A review. Cement and Concrete Composite, 68, 96-108. https://doi.org/10.1016/j.cemconcomp.2016.02.014

Ramamurthy, K., Nambiar, E. K. K., \& Ranjani, G. I. S. (2009). A classification of studies on properties of foam concrete. Cement and Concrete Composites, 31(6), 388-396. https://doi.org/10.1016/j. cemconcomp.2009.04.006

Sari, K. A. M., \& Sani, A. R. M. (2017). Applications of foamed lightweight concrete. MATEC Web of Conferences, 97, 1-5. https://doi.org/10.1051/matecconf/20179701097

Serri, E., Mydin, M. A. O., \& Suleiman, M. Z. (2014). Thermal properties of oil palm shell lightweight concrete with different mix designs. Jurnal Teknologi, 70(1), 155-159. https://doi.org/10.11113/jt.v70.2507 
Suhendro, B. (2014). Toward green concrete for better sustainable environment. Procedia Engineering, 95, 305-320. https://doi.org/10.1016/j.proeng.2014.12.190

Tangchirapat, W., \& Jaturapitakkul, C. (2010). Strength, drying shrinkage, and water permeability of concrete incorporating ground palm oil fuel ash. Cement and Concrete Composites, 32(10), 767-774. https://doi. org/10.1016/j.cemconcomp.2010.08.008

Thakrele, M. H. (2014). Experimental study on foam concrete. International Journal of Civil, Structural, Environmental and Infrastructure Engineering Research and Development, 4(1), 145-158. 